\title{
The accident at Chernobyl and outcome of pregnancy in Finland
}

\author{
T Harjulehto, T Aro, H Rita, T Rytömaa, L Saxén
}

\begin{abstract}
Objective-To evaluate the outcome of pregnancy in Finnish women after the accident at the Chernobyl nuclear power plant on 26 April 1986.

Design-Geographic and temporal cohort study.

Setting - Finland divided into three zones according to amount of radioactive fallout.

Subjects-All children who were exposed to radiation during their fetal development. Children born before any effects of the accident could be postulated - that is, between 1 January 1984 and 30 June 1986-served as controls.
\end{abstract}

Interventions-Children were divided into three temporal groups: controls, children who were expected to be born in August to December 1986, and children who were expected to be born in February to December 1987. They were also divided, separately, into three groups according to the three geographic zones.

End point-Incidence of congenital malformations, preterm births, and perinatal deaths.

Measurements and main results-There were no significant differences in the incidence of malformations or perinatal deaths among the three temporal and three geographic groups. A significant increase in preterm births occurred among children who were exposed to radiation during the first trimester whose mothers lived in zones 2 and 3, where the external dose rate and estimated surface activity of caesium137 were highest.

Conclusions - The results suggest that the amount of radioactive fallout that Finnish people were exposed to after the accident at Chernobyl was not high enough to cause fetal damage in children born at term. The higher incidence of premature births among malformed children in the most heavily polluted areas, however, remains unexplained.

\section{Introduction}

Experimental investigations have shown that Departments of Pathology and Public Health, University of Helsinki, Haartmaninkatu 3 , SF-00290 Helsinki, Finland $\mathrm{T}$ Harjulehto, MD, research associate

L Saxén, MD, professor of pathology

T Aro, MD, associate professor of public health

H Rita, MPOLSC, system analyst

Finnish Centre for Radiation and Nuclear Safety, Elimäenkatu 25A, SF-00510 Helsinki, Finland

T Rytömaa, MD, professor

Correspondence to: Prof Saxén.

Br Med $\mathcal{f}$ 1989;298:995-7 the radiation soon after the accident, when information was still incomplete and inadequate. Malformations in domestic animals were described, and people were warned against eating freshwater fish and vegetables.
Cattle were not allowed to enter polluted pastures, and sand was replaced in children's playgrounds. The confusion in Finland and elsewhere in Europe subsided after adequate information was made available, but alarming reports and views on fetal damage persisted. ${ }^{10}$ Hence we thought that the outcome of pregnancy after the accident should be analysed and reported despite the low amount of radiation to which the population had been exposed.

Details of the accident-The accident occurred early in the morning of 26 April 1986 at the nuclear power plant in Chernobyl, in the south west of the Soviet Union. The explosions and the subsequent fire released large amounts of radioactive substances into the atmosphere, which spread rapidly to southern Scandinavia and Finland (figs 1 and 2). Analyses showed that the amounts of caesium-137 deposited were closely related to rainfall intercepting the plume of radioactive substances. ${ }^{12}$ Because of great differences in rainfall during the critical period the doses of radiation in Finland varied greatly, ranging initially from zero to about $4 \mu \mathrm{Sv} / \mathrm{h}$. The final estimates for the fallout of caesium-137 were based on 850 measurements covering the 462 Finnish municipalities. These were grouped subsequently into three zones according to the amount of radiation (fig 2). The estimated maximum dose of radiation from the fallout to an embyro, integrated over the first month after the accident (fig 3), was about $1 \mathrm{mSv}$.

\section{Subjects and methods}

Data on the outcome of pregnancy were collected from the Finnish register of congenital malformations ${ }^{13}$ and pooled with data from the central statistical office

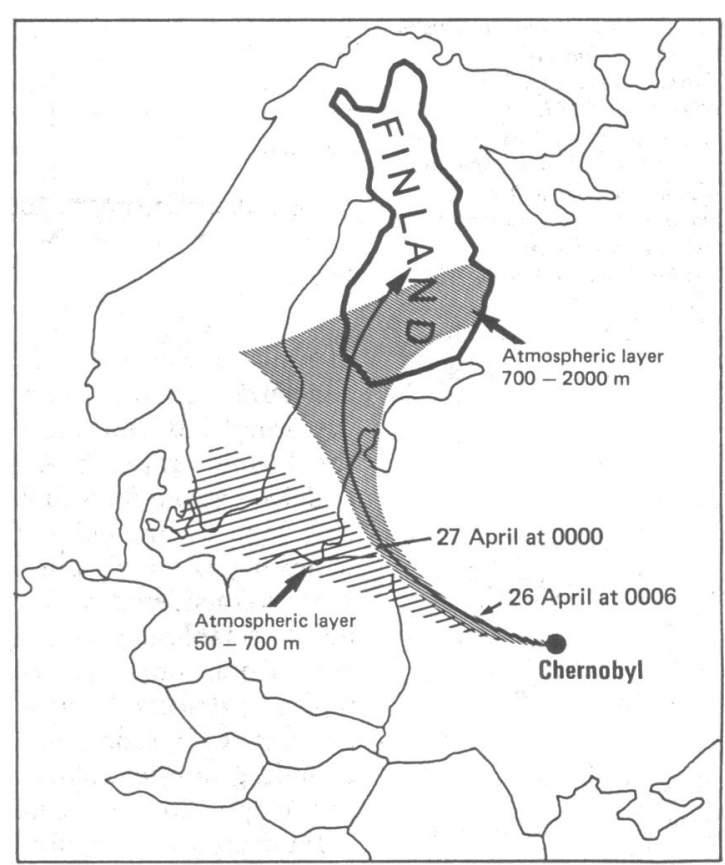

FIG 1-Transport of radioactive substances from Chernobyl during early stages after accident" 


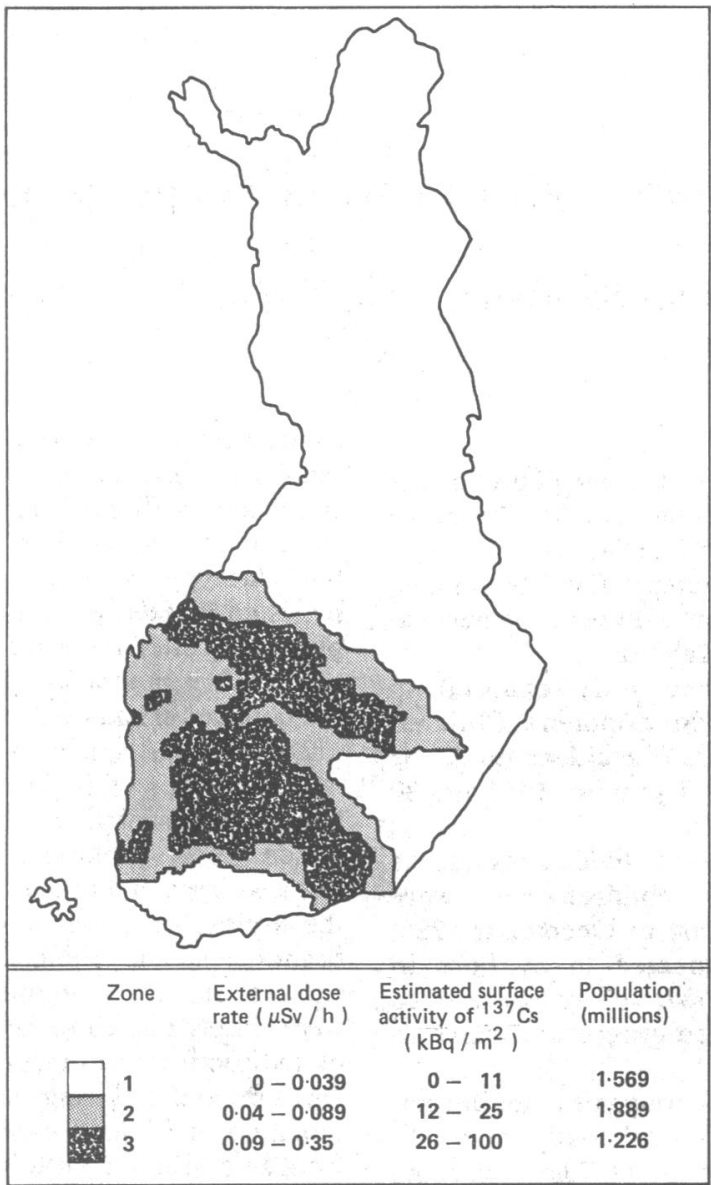

FIG 2-External dose rate in October 1986 and estimated surface activity of ${ }^{137} \mathrm{C}$ s caused by fallout in Finland after acciden at Chernobyl"

FIG 3-External dose rate caused by fallout at town of Uusikaupunki $\left(21^{\circ} 24^{\prime} E\right.$, $60^{\circ} 48^{\prime} N$ ) in 1986. "Most important contribution to initial dose rate (peak) came from shor lived iodine-131, iodine-132, and lanthanum-140; after this dose rate was dominated by caesium-134 and caesium-137 rates of detection and reporting - namely, malformations of the central nervous system, orofacial clefts, and reduction limb defects. The expected dates of birth of the children were recorded as well as the municipalities where the mothers lived during pregnancy. Children were divided into three temporally and three geographically distinct groups. Children born before any effects of the accident could be postulated - that is, between 1 January 1984 and 30 June 1986-served as controls. The children who had been in the first six months of their fetal development during the accident should have been born in the period between 31 July 1986 and 17 January 1987 . After the borderline months July and January were excluded from the study one study group consisted of children exposed to radiation with expected dates of birth in August to December 1986 and another of children with expected dates of birth in February to December 1987. The children in the latter group had been conceived after the accident but had possibly been exposed to radioactivity remaining in the soil and water during their fetal development.

Geographically the cases were divided according to the three zones of Finland shown in figure 2. The populations of the zones were about the same-namely, $1 \cdot 6,1 \cdot 9$, and $1 \cdot 2$ million.

The incidence of congenital malformations, the number of preterm deliveries of malformed children, and the number of perinatal deaths were compared in the temporal groups by a $\chi^{2}$ test ${ }^{15}$ and, separately, in the three geographic populations.

\section{Results}

Table I gives the incidence of all teratologic malformations in the three temporal and the three geographic groups. No significant differences were found. The expected and observed numbers of malformations in the three groups did not differ significantly (table II).

TABLE I - Incidence of all malformations in children born in Finland in three zones (with $95 \%$ confidence intervals)

\begin{tabular}{|c|c|c|c|c|c|c|}
\hline \multirow[b]{3}{*}{ Zone } & \multicolumn{6}{|c|}{ Date of birth } \\
\hline & \multicolumn{2}{|c|}{$\begin{array}{l}1 \text { Jan } 1984- \\
\text { 30 June } 1986\end{array}$} & \multicolumn{2}{|c|}{$\begin{array}{l}\text { 1 Aug 1986- } \\
\text { 31 Dec } 1986\end{array}$} & \multicolumn{2}{|c|}{$\begin{array}{l}1 \text { Feb } 1987- \\
31 \text { Dec } 1987\end{array}$} \\
\hline & $\begin{array}{l}\text { No of } \\
\text { cases }\end{array}$ & $\begin{array}{c}\text { Prevalence } \\
(\%)\end{array}$ & $\begin{array}{l}\text { No of } \\
\text { cases }\end{array}$ & $\begin{array}{c}\text { Prevalence } \\
(\%)\end{array}$ & $\begin{array}{l}\text { No of } \\
\text { cases }\end{array}$ & $\begin{array}{c}\text { Prevalence } \\
(\%)\end{array}$ \\
\hline $\begin{array}{l}1 \\
2 \\
3\end{array}$ & $\begin{array}{l}597 \\
711 \\
452\end{array}$ & $\begin{array}{l}1.0(0.9 \text { to } 1 \cdot 1) \\
1.2(1.1 \text { to } 1.3) \\
1.2(1.1 \text { to } 1.3)\end{array}$ & $\begin{array}{r}103 \\
122 \\
77\end{array}$ & $\begin{array}{l}1.1(0.9 \text { to } 1.3) \\
1.3(1.1 \text { to } 1.5) \\
1.4(1.1 \text { to } 1.7)\end{array}$ & $\begin{array}{l}218 \\
223 \\
144\end{array}$ & $\begin{array}{l}1 \cdot 0(0.9 \text { to } 1 \cdot 1) \\
1 \cdot 1(1.0 \text { to } 1.2) \\
1 \cdot 1(0.9 \text { to } 1.3)\end{array}$ \\
\hline otal & 1760 & $1.1(1.1$ to 1.2$)$ & 302 & $1.2(1.1$ to 1.3$)$ & 585 & $1 \cdot 1(1.0$ to 1.2$)$ \\
\hline
\end{tabular}

Preterm births (duration of pregnancy 38 weeks or less) among the malformed children were significantly more common among those exposed to radiation during their first trimester in zones 2 and 3 (tables II and III). There were no differences in the incidence of perinatal deaths among the three temporal periods in the three geographic groups (table II). Table IV shows that overall the number of induced abortions decreased slightly in Finland during 1985-7, and no change in this trend was detected in the months after the accident at Chernobyl.

The yearly number and monthly distribution of all births was obtained from the central statistical office of Finland. From the percentage monthly distribution of the births we estimated that the birth rate was slightly lower than expected during January to March 1987; for births during these months conceptions would have occurred in the first months after the accident. The total decrease was about 350 children $(0.5 \%$ of the total number of births in Finland each year). 
TABLE II-Expected and observed numbers of reported malformations and of preterm deliveries and perinatal deaths of malformed infants in Finland after accident at Chernobyl

\begin{tabular}{|c|c|c|c|c|c|c|c|c|c|c|c|c|c|c|c|c|}
\hline & \multicolumn{4}{|c|}{ Zone 1} & \multicolumn{4}{|c|}{ Zone 2} & \multicolumn{4}{|c|}{ Zone 3} & \multicolumn{4}{|c|}{ Total } \\
\hline & \multicolumn{2}{|c|}{$\begin{array}{l}\text { Period } 1 \dagger \\
(\mathrm{n}=9318)\end{array}$} & \multicolumn{2}{|c|}{$\begin{array}{c}\text { Period } 2 \ddagger \\
(\mathbf{n}=21228)\end{array}$} & \multicolumn{2}{|c|}{$\begin{array}{l}\text { Period } 1 \dagger \\
(n=9368)\end{array}$} & \multicolumn{2}{|c|}{$\begin{array}{c}\text { Period } 2 \ddagger \\
(n=20896)\end{array}$} & \multicolumn{2}{|c|}{$\begin{array}{l}\text { Period } 1 \dagger \\
(\mathbf{n}=5617\end{array}$} & \multicolumn{2}{|c|}{$\begin{array}{c}\text { Period } 2 \ddagger \\
(\mathrm{n}=12748)\end{array}$} & \multicolumn{2}{|c|}{$\begin{array}{c}\text { Period } 1 \dagger \\
(n=24303)\end{array}$} & \multicolumn{2}{|c|}{$\begin{array}{c}\text { Period } 2 \ddagger \\
(n=54874)\end{array}$} \\
\hline & Expect & Observed & Expect & Observed & Expecte & Observed & Expecte & Observed & Expect & Observed & Expecte & Observed & Expected & Observed & Expect & bserved \\
\hline \multicolumn{17}{|l|}{ Malformations: } \\
\hline $\begin{array}{l}\text { Total } \\
\text { Defects of central }\end{array}$ & 94 & 103 & 213 & 218 & 110 & 122 & 246 & 223 & 68 & 77 & 153 & 144 & 272 & 302 & 614 & 585 \\
\hline nervous system & 5 & 6 & 12 & 12 & 7 & 4 & 15 & 11 & 3 & 0 & 7 & 6 & 15 & 10 & 34 & 29 \\
\hline Orofacial clefts & 22 & 16 & 50 & 49 & 21 & 22 & 47 & 44 & 9 & 11 & 21 & 24 & 52 & 49 & 117 & 117 \\
\hline Reduction limb defects & 4 & 4 & 9 & 11 & 5 & 4 & 11 & 6 & 3 & 3 & 6 & 4 & 12 & 12 & 26 & 21 \\
\hline Preterm deliveries & 21 & 26 & 47 & 50 & 22 & 35 & 48 & 39 & 10 & 23 & 23 & 33 & 53 & 84 & 119 & 122 \\
\hline Perinatal deaths & 13 & 11 & 30 & 33 & 11 & 21 & 25 & 23 & 7 & 8 & 16 & 17 & 32 & 40 & 71 & 73 \\
\hline
\end{tabular}

^Expected numbers were calculated from figures for January 1984 to June 1986. Total number of deliveries were: zone 1, 59482; zone 2, 60286 ; zone 3, 37606.

†August to December 1986.

tFebruary to December 1987.

TABLE III-Incidence of preterm deliveries of malformed infants in Finland in three zones (with 95\% confidence intervals)

\begin{tabular}{|c|c|c|c|c|c|c|}
\hline \multirow[b]{3}{*}{ Zone } & \multicolumn{6}{|c|}{ Date of birth } \\
\hline & \multicolumn{2}{|c|}{1 Jan 1984-30 June 1986} & \multicolumn{2}{|c|}{1 Aug 1986-31 Dec 1986} & \multicolumn{2}{|c|}{1 Feb 1987-31 Dec 1987} \\
\hline & No of cases & Prevalence (\%) & No of cases & Prevalence (\%) & No of cases & Prevalence $(\%)$ \\
\hline 1 & 132 & $0.22(0.18$ to 0.26$)$ & 26 & $0.28(0.17$ to 0.39$)$ & 50 & $0.24(0.17$ to 0.30$)$ \\
\hline 2 & 139 & $0.23(0.19$ to 0.27$)$ & 35 & $0.37(0.25$ to 0.49$)$ & 39 & $0 \cdot 19(0.13$ to 0.25$)$ \\
\hline 3 & 69 & $0.18(0.14$ to 0.22$)$ & 23 & $0.40(0.24$ to 0.56$)$ & 33 & $0 \cdot 25(0 \cdot 16$ to $0 \cdot 34)$ \\
\hline Total & 340 & $0.22(0.20$ to 0.24$)$ & 84 & $0.34(0.27$ to 0.41$)$ & 122 & $0.22(0.18$ to 0.26$)$ \\
\hline
\end{tabular}

TABLE IV-Monthly average numbers (SD) of induced abortions in Finland during 1985-7 (central statistical office of Finland)

\begin{tabular}{llll}
\hline & 1985 & \multicolumn{1}{c}{1986} & \multicolumn{1}{c}{1987} \\
\hline Jan-April & $1135(134)$ & $1070(115)$ & $1070(101)$ \\
May-July & $1088(130)$ & $1049(57)$ & $1069(39)$ \\
Aug-Dec & $1083(85)$ & $1061(37)$ & $1086(67)$ \\
\hline
\end{tabular}

\section{Discussion}

Based on the observations in a population of about five million with about 60000 deliveries each year we conclude that after the radioactive fallout caused by the accident at the Chernobyl nuclear power plant the incidence of congenital malformations and perinatal deaths did not increase. This finding agrees with results of similar epidemiological studies in Sweden and Hungary ${ }^{67}$ and also with predictions based on the very low amount of radioactivity in these countries as well as previous experimental and empirical data on the harmful effects of ionising radiation. ' We emphasise, however, that we did not study the possibility of genetic damage in the children exposed to radiation during their fetal development.
The fact that no increase was observed in the number of induced abortions after news of the accident spread suggests that despite the sensational information no serious panic occurred among pregnant women or their doctors. The low birth rate after the accident can be explained by the hesitation of some women to become pregnant soon after the accident. The increased incidence of preterm deliveries of malformed infants remains unexplained.

1 Brent RL. Radiation teratogenesis. Teratology 1980;21:281-98.

2 Brent RL. The effects of embryonic and fetal exposure to $\mathrm{x}$-ray, microwaves, and ultrasound. Clin Perinatol 1986;13:615-48.

3 Edwards FM. Dose-response models and methods of risk prediction and causation estimation. Semin Nucl Med 1986;16:118-30.

4 Otake $M$, Schull WJ. In utero exposure to A-bomb radiation and menta retardation: a reassessment. Br $\mathcal{F}$ Rudiol 1984;57:409-14.

5 Hinz G, Kaul A. Strahlenbelastung und Schwangerschaft. Gynakologe 1987;20:137-43.

6 Källen B. Pregnancy outcome in Sweden after Chernobyl-study with centr health registries. Stockholm: National Board of Health and Welfare of Sweden, 1988:1-47. (Report No 33621-348/88.)

7 Czeizel E, Billege B. A Csernobili atomerömu-baleset teratológiai értékelése Magyarországon. (Teratological evaluation of Hungarian pregnancy out comes after the accident in the nuclear power station of Chernobyl.) Orvo Hetilap 1988;129:457-62.

8 Trichopoulos D, Zavitsanos X, Koutis C, Drogari P, Proukakis C, Petridoi E. The victims of Chernobyl in Greece: induced abortions after the acciden Br Med f 1987;295:1100.

9 Selbmann HK. Tschernobyl und kein Ende. Fortschr Med 1987;105:14-5.

10 Moser E, Roedler HD. "Jod: Biokinetik, Strahlenexposition sowie Risikoabschätzung im Zusammenhang mit dem Reaktorunfall in Tschernobyl. ROFO 1987:146:711-6.

11 Arvela H, Blomqvist L, Lemmelä H, Savolainen AL, Sarkkula S. Environmental gamma radiation measurements in Finland and the influence of mental gamma radiation measurements in Finland and the infuence of 1987. Suppand 10 to STUK-A55, 1987, Annual Report of the Finnish Centre for Radiation and Nuclear Safety.

12 Clark MJ, Smith FB. Wet and dry deposition of Chernobýl releases. Nature 1988;332:245-9.

13 Saxén L, Klemetti A, Härö SA. A matched-pair register for studies of selected congenital defects. Am J Epidemiol 1974; 100:297-306.

14 Saxén L. Twenty years of study of the etiology of congenital malformations in Finland. In: Kalter $\mathrm{H}$, ed. Issues and reviews in teratology. Vol 1. New York: Plenum Press, 1983:73-110.

15 Fleiss JL. Statistical methods for rates and proportions. New York: Wiley, 1980:139.

(Accepted 31 fanuary 1989)

\section{ONE HUNDRED YEARS AGO}

Though not technically winter, the weather of the first week of March has been wintry. Owing to the mildness which prevailed from November to the middle of February, it can already be recorded as a fact that the winter of 1888-9 will not be long. It may be, or rather is, late, but several winter months have passed and the weather has been, as a rule, mild. The cold of the last week has been characterised by the coincidence, by no means constant, of east wind and frost, a subject of interest to the profession. Altogether, February was "good for the country," though bad for infants, invalids, and the aged. Countrymen have dubbed that month "fill-dyke," and the rhyme wherein that expression is to be found asserts, not untruly, that it is best that the dyke be filled with white rather than with black. So has it happened in 1889; snow has prevailed over rain. A cold March suggests the question of the true length of severe winters in the British Islands. Reference to history will show that these exceptional winters either consisted of intense frost about Christmas week, the ice "not bearing a goose after Yule-tide," or of several weeks of moderate but steady frost early in the year. These long frosts (1715-16, $1788-9,1794-5,1855$, and 1860-1) all broke up about the middle of February. The long frost of $1879-80$ lasted into March. The truth remains that the month of March, 1889, has been very cold throughout its first week. We observed, a few weeks since, that mild winters are, taken as a whole, a blessing. On the other hand, hard frost with east wind is not necessarily a curse. The chief danger in March winds is the fact that the sun often shines, the temperature remaining relatively low. Hence indoors and in streets and public promenades the weather feels pleasant. Persons are therefore apt to go out not very warmly clad, and a few minutes' exposure to the wind, or even a few minutes of clouding over of the sun, may spread bronchitis and pneumonia broadcast. During the past week the frost has reminded everybody to wrap up well; so, in defying the frost the public has not been thrown off its guard by the sun to fall victims to the treacherous east wind. (British Medical fournal 1889;i:543) 